\title{
Low grade B cell mucosa associated lymphoid tissue lymphoma of the stomach: clinical and endoscopic features, treatment, and outcome
}

\author{
M Blazquez, C Haioun, M-T Chaumette, P Gaulard, F Reyes, J-C Soulé, J-C Delchier
}

\begin{abstract}
A retrospective study of the clinical and endoscopic features of low grade gastric lymphomas of mucosa associated lymphoid tissue (MALT) in 16 patients together with treatment and outcome was undertaken. Immunohistochemical studies of fresh tissue easily distinguished MALT lymphoma from benign reactive lymphoid hyperplasia (pseudolymphoma) and showed that tumour cells had the characteristic phenotype indicative of their origin from MALT. Persistant epigastric pain was the main presenting complaint, and was often associated with acute bleeding, anaemia, or weight loss. Eight patients had a past history of recurrent peptic ulcers or gastritis. The endoscopic appearance suggested malignancy in only half the cases and was compatible with gastritis or a benign peptic ulcer in the remainder. There was extragastric involvement of other mucosal sites in eight patients (mainly the lung, but also the parotid gland and small bowel), but rarely was bone marrow and never the spleen or peripheral lymph nodes affected. Conservative treatment with long term cyclophosphamide was effective in both stage I and stage IV disease, and all the patients are alive after a median follow up of 4.5 years. These findings confirm that low grade gastric MALT lymphomas are usually indolent tumours with non-specific endoscopic aspects and show that dissemination to other mucosal sites was more frequent than previously reported. Monochemotherapy could be an effective alternative treatment to surgery.
\end{abstract}

(Gut 1992; 33: 1621-1625)

Services d'Hépato-

Gastroentérologie et d'Hématologie et

Laboratoire

d'Anatomopathologie,

Centre Hospitalier

Universitaire Henri

Mondor, Créteil, France

M Blazquez

C Haioun

M-T Chaumette

P Gaulard

F Reyes

J-C Soulé

J-C Delchier

Correspondence to:

Dr J-C Delchier, Service

d'Hépato-Gastroentérologie, Centre Hospitalie

Universitaire Henri Mondor,

51 avenue du Maréchal

Delattre de Tassigny, 94010

Créteil Cedex, France.

Accepted for publication

27 April 1992
The gastrointestinal tract, particularly the stomach, is the most common primary site of mas are large cell lymphomas of B cell lineage. ${ }^{23}$ Primary small cell gastric lymphomas are less frequent and are usually localised, solitary lesions that can be completely excised. Because of their favourable prognosis, they were long known as pseudolymphomas. ${ }^{47}$ However, immunohistochemical methods have now shown that most of these tumours are monoclonal B cell proliferations. ${ }^{8-11}$ A number of recent pathological studies have emphasised the specificity of these B cells, suggesting that they originate from mucosa associated lymphoid tissue (MALT). ${ }^{12-14}$ Indeed, they have the same cytological and immunophenotypic characteristics as the B cells that are normally found around the mantle zone of Peyer's patches. These properties are now extranodal lymphomas. ${ }^{1}$ Most gastric lympho- commonly used by pathologists in the diagnosis of MALT lymphomas. A large clinicopathological study based on the review of surgical specimens has recently confirmed results from previous shorter series. ${ }^{131516}$ by showing the good prognosis of small cell gastric lymphomas from MALT origin. ${ }^{17}$

Details of symptoms and endoscopic aspects of the stomach in this type of lymphoma, however, remain scarce in the published reports, and the best treatment has not yet been established. This prompted us to report 16 consecutive cases of low grade gastric MALT lymphomas diagnosed in our institution. In this series, the histological diagnosis was based on biopsy specimens, staging procedures systematically included abdominal and chest computed tomography and bone marrow biopsy, and most patients were not operated on but were successfully treated with monochemotherapy.

\section{Patients and methods}

\section{PATIENTS}

Sixteen patients with low grade gastric MALT lymphoma diagnosed in our institution between 1980 and 1990 were reviewed. The patients, nine men and seven women, ranged in age from 25 to 70 years, with a mean of 54 years

DIAGNOSTIC PROCEDURES

Fifteen patients were referred to our endoscopic unit for the investigation of epigastric pain, sometimes associated with acute bleeding or anaemia. Several biopsy specimens $(>6)$ were taken, with forceps in every case. One patient with an established diagnosis was referred for additional treatment after partial gastrectomy. The diagnosis of lymphoma was based on histological and immunophenotypic criteria. ${ }^{12}$

Tissue specimen preparation

Tissue specimens were processed for routine

TABLE I Antibody panel

\begin{tabular}{lll}
\hline Antigen & Antibody & Pattern of reactivity \\
\hline CD 3 & Anti-Leu 4 & T lymphocyte \\
CD 4 & Anti-Leu 3a & Thelper lymphocyte \\
CD 5 & Anti-Leu 1 & T lymphocyte, subset of B-cells \\
CD 8 & Anti-Leu 2 & Cytotoxic/suppressor T lymphocyte \\
CD 19 & B 4 & B lymphocyte \\
CD 22 & Anti-K, i.. \%, $\mu, \delta$ & B lymphocyte \\
- & Light and heavy chains \\
\hline
\end{tabular}

The Leu series was obtained from Becton Dickinson \& $\mathrm{C}_{0}$ Mountain View, CA, USA. B4 antibody and Ig chain antibodies were obtained from Coulter Immunology, Hialeah, FL, USA CD 22 antigen was obtained from Dakopatts AIS, Glostrup, Denmark. 
histology and immunohistology. In each case, several tissue specimens were fixed with aqueous Bouin's solution. Paraffin embedded sections were stained for conventional study with haematoxylin-eosin-safran (HES) and periodic acid Schiff (PAS). In 12 of the 16 cases, fresh tissue specimens were snap frozen in liquid nitrogen after $\mathbf{3 0}$ minutes' incubation in gum sucrose for immunohistological studies.

\section{Immunophenotypic studies}

Deparaffinised and cryostat sections of the gastric biopsy specimens were evaluated for the presence of various antigens using the immunoalkaline phosphatase method (APAAP). ${ }^{19}$ The monoclonal antibodies used, their specific immunoreactivities and commercial sources are shown in Table I. Rabbit antimouse immunoglobulins and alkaline phosphataseantiphosphatase complexes were purchased from DAKO (Dakopatts A/S, Glostrup, Denmark). Alkaline phosphatase activity was determined after incubation in fast-red TR (1 $\mathrm{mg} / \mathrm{ml}$, Sigma Chemical Company, St Louis, MO, USA) and naphthol AS-TR phosphate ( 0.2 $\mathrm{mg} / \mathrm{ml}$, Sigma) solution, which contained levamisole $(0.24 \mathrm{~g} / \mathrm{ml})$ to block endogenous alkaline phosphatase activity.

\section{STAGING PROCEDURES}

Staging systematically included a bone marrow biopsy, chest and abdominal computed tomography, oropharyngolarynx examination, and liver function tests. A small bowel barium meal and colonoscopy were performed in eight cases and gastric endosonography was performed in one patient. The patients were staged using the Ann Arbor system. ${ }^{20}$

\section{TREATMENT}

In 14 of the 16 patients, initial treatment was an alkylating agent alone (cyclophosphamide 100 $\mathrm{mg} /$ day). This monochemotherapy was continued until complete remission was obtained (normal appearance of the gastric mucosa, negative biopsy specimens, and absence of extragastric localisation). One patient with a severe form of the disease (large tumour, poor general condition, and a rapid course) was treated with an anthracin-containing regimen (cyclophosphamide, adriamycin, vincristine, prednisone) combined with radiotherapy ( 25 Grays). Another had been operated on (partial gastrectomy) before referral to our institution and received additional radiation therapy ( 30 Grays).

\section{FOLLOW UP}

Endoscopy with biopsies was repeated every three months in every case. Chest and abdominal computed tomography was performed every six months when lymph node or lung involvement was present at the initial staging. Patients who achieved complete remission underwent endoscopy with biopsies every six months.

Complete remission was defined as resolution of clinical evidence of disease and of endoscopic lesions, with negative biopsy specimens and absence of extragastric localisation. Partial remission was defined as improvement of clinical symptoms and endoscopic lesions with a decrease in tumoral infiltration.

Analysis was performed in November 1991

TABLE II Clinical features

\begin{tabular}{|c|c|c|c|c|c|c|c|c|}
\hline $\begin{array}{l}\text { Case } \\
\text { no }\end{array}$ & $\underset{(y r)}{A g e}$ & Sex & $\begin{array}{l}\text { Presenting symptoms } \\
\text { (duration) }\end{array}$ & Past history & $\begin{array}{l}\text { Extent of disease } \\
\text { (stage) }\end{array}$ & Endoscopic findings & $\begin{array}{l}\text { Treatment } \\
\text { (duration) }\end{array}$ & Follow up \\
\hline 1 & 52 & $\mathbf{F}$ & $\begin{array}{l}\text { Epigastric pain, weight } \\
\text { loss } 10 \mathrm{~kg}\end{array}$ & $\begin{array}{l}\text { Gastric ulcer, gastric } \\
\text { bleeding }\end{array}$ & I & $\begin{array}{l}\text { Thickening of folds and } \\
\text { erosions of angulus }\end{array}$ & $\begin{array}{l}\text { Cyclophosphamide } \\
\text { (1 year) }\end{array}$ & 18 months $^{\star}$ \\
\hline 2 & 58 & $\mathbf{M}$ & $\begin{array}{l}\text { Epigastric pain (6 } \\
\text { months), bleeding }\end{array}$ & $\begin{array}{l}\text { Gastric ulcer, gastric } \\
\text { bleeding }\end{array}$ & I & $\begin{array}{l}\text { Suspectt ulcer of the } \\
\text { gastric body }\end{array}$ & $\begin{array}{l}\text { Cyclophosphamide } \\
\text { (9 months) }\end{array}$ & 18 months $^{\star}$ \\
\hline 3 & 62 & $\mathbf{F}$ & $\begin{array}{l}\text { Epigastric pain (5 years), } \\
\text { weight loss } 7 \mathrm{~kg}\end{array}$ & $\begin{array}{l}\text { Gastritis, pseudolymphoma } \\
\text { (3 years) }\end{array}$ & I & $\begin{array}{l}\text { Thickening of gastric } \\
\text { folds, erosions }\end{array}$ & Cyclophosphamide & Lost to follow-up \\
\hline 4 & 72 & $\mathbf{M}$ & Epigastric pain (1 year) & - & I & $\begin{array}{l}\text { Suspect ulcer of the } \\
\text { antrum + small nodules, } \\
\text { thickening of folds }\end{array}$ & $\begin{array}{l}\text { Surgery, } \\
\text { radiotherapy }\end{array}$ & 7 years ${ }^{\star}$ \\
\hline 5 & 50 & $\mathbf{F}$ & $\begin{array}{l}\text { Epigastric pain (1 year), } \\
\text { weight loss } 2 \mathrm{~kg}\end{array}$ & - & I & $\begin{array}{l}\text { Small nodules of the } \\
\text { antrum }\end{array}$ & Cyclophosphamide & Lost to follow-up \\
\hline 6 & 65 & $\mathbf{M}$ & Epigastric pain (5 years) & Gastritis & I & $\begin{array}{l}\text { Thickening of gastric folds } \\
\text { in body }\end{array}$ & $\begin{array}{l}\text { Cyclophosphamide } \\
\text { (1 year) }\end{array}$ & 3 years $\star$ \\
\hline 7 & 25 & $\mathbf{F}$ & $\begin{array}{l}\text { Epigastric pain (1 year), } \\
\text { anemia }\end{array}$ & - & I & $\begin{array}{l}\text { Ulcerative mass of angulus } \\
\text { and body, thickening of } \\
\text { folds in antrum }\end{array}$ & $\begin{array}{l}\text { Polychemotherapy } \\
\text { (CHOP), } \\
\text { radiotherapy }\end{array}$ & 4 years $^{\star}$ \\
\hline 8 & 56 & $\mathbf{M}$ & Gastric bleeding & - & I & Suspect ulcer of the body & $\begin{array}{l}\text { Cyclophosphamide } \\
\text { (1 year) }\end{array}$ & 1 year ${ }^{\star}$ \\
\hline 9 & 55 & $\mathbf{M}$ & $\begin{array}{l}\text { Epigastric pain, weight } \\
\text { loss } 10 \mathrm{~kg}\end{array}$ & Pseudolymphoma ( 10 years) & $\begin{array}{l}\text { IV (regional lymph } \\
\text { nodes lung) }\end{array}$ & $\begin{array}{l}\text { Thickening of gastric folds } \\
\text { in body and antrum } \neq\end{array}$ & $\begin{array}{l}\text { Cyclophosphamide } \\
\text { (1 year) }\end{array}$ & $\begin{array}{l}1 \text { year partial } \\
\text { remission }\end{array}$ \\
\hline 10 & 67 & $\mathbf{M}$ & $\begin{array}{l}\text { Epigastric pain ( } 2 \\
\text { months), weight loss } \\
5 \mathrm{~kg}\end{array}$ & $\begin{array}{l}\text { Bleeding ulcer requiring } \\
\text { surgery ( } 7 \text { years) }\end{array}$ & IV (lung) & $\begin{array}{l}\text { Small nodules in gastric } \\
\text { stump }\end{array}$ & $\begin{array}{l}\text { Cyclophosphamide } \\
\text { (6 months) }\end{array}$ & 1 year $^{\star}$ \\
\hline 11 & 53 & $\mathbf{M}$ & Epigastric pain (1 year) & - & IV (bone marrow) & Suspect ulcer of the body & $\begin{array}{l}\text { Cyclophosphamide } \\
\text { (1 year) }\end{array}$ & 5 years ${ }^{\star}$ \\
\hline 12 & 70 & $\mathrm{~F}$ & Gastric bleeding & $\begin{array}{l}\text { Pseudolymphoma of lung } \\
\text { and parotid glands }\end{array}$ & IV (lung) & Suspect ulcer of angulus & $\begin{array}{l}\text { Cyclophosphamide } \\
\text { (2 years) }\end{array}$ & $\begin{array}{l}\text { Relapse at } 6 \text { years, } \\
\text { partial remission } \\
7 \text { years }\end{array}$ \\
\hline 13 & 57 & $\mathbf{F}$ & Epigastric pain ( 3 years) & $\begin{array}{l}\text { Gastric ulcer, gastritis, lung } \\
\text { lymphoma }\end{array}$ & $\begin{array}{l}\text { IV (lung, bone } \\
\text { marrow) }\end{array}$ & Thickening of antrum & $\begin{array}{l}\text { Cyclophosphamide } \\
\text { (1 year) }\end{array}$ & $\begin{array}{l}\text { Relapse at } 6 \text { years, } \\
\text { small bowel, } \\
\text { stomach, and lung }\end{array}$ \\
\hline 14 & 50 & $\mathbf{M}$ & Epigastric pain, anaemia & - & $\begin{array}{l}\text { IV (lung mediastinal } \\
\text { lymph nodes) }\end{array}$ & Suspect ulcer of body & $\begin{array}{l}\text { Cyclophosphamide } \\
\text { (1 year) }\end{array}$ & 6 years ${ }^{\star}$ \\
\hline 15 & 54 & F & Epigastric pain & $\begin{array}{l}\text { Recurrent gastric ulcer, } \\
\text { gastric bleeding }\end{array}$ & IV (lung) & Ulcer of body & $\begin{array}{l}\text { Cyclophosphamide } \\
\text { (1 year) }\end{array}$ & 18 months $^{\star}$ \\
\hline 16 & +2 & $\mathbf{M}$ & Epigastric pain (6 months) & Lung lymphoma & IV (lung) & $\begin{array}{l}\text { Diffuse small nodules, } \\
\text { erosions }\end{array}$ & $\begin{array}{l}\text { Cyclophosphamide } \\
\text { (2 years) }\end{array}$ & $\begin{array}{l}\text { Relapse at } 7 \text { years, } \\
\text { partial remission } \\
7 \cdot 5 \text { years }\end{array}$ \\
\hline
\end{tabular}


providing minimum and median follow up of 1 and 4.5 years respectively.

\section{Results}

\section{CLINICAL FEATURES}

The main characteristics of the patients are given in Table II.

Persistent epigastric pain lasting from 6 months to 5 years was the predominant complaint, associated with acute gastric bleeding in three patients, anaemia in two (haemoglobin $<10 \mathrm{~g} / \mathrm{dl})$, and weight loss $(>5 \mathrm{~kg})$ in five at the time of diagnosis. Eight patients had a past history of recurrent gastric ulcer $(n=5)$, endoscopic gastritis $(n=3)$, or gastrointestinal bleeding $(n=4)$ from 2 to 10 years before diagnosis. One patient had been operated on (partial gastrectomy) for a bleeding ulcer seven years previously. Two patients had a past history of small cell lung lymphoma treated surgically $(n=1)$ or with chemotherapy $(n=1)$. One of the latter patients had previously presented with a parotid gland localisation.

\section{ENDOSCOPIC ASPECTS}

Endoscopic lesions affected the body of the stomach in seven cases, the antrum in five, and both the body and the antrum in four. In eight cases, the lesion consisted of an irregular and large ulcer with raised edges and was highly suggestive of malignancy. In the other eight cases endoscopy showed only lesions of a benign nature (erythematous gastritis, erosions, small nodules, localised or diffuse thickening of gastric folds).

\section{PATHOLOGICAL STUDY}

\section{Biopsy specimens}

In 15 of 16 patients the diagnosis was based on multiple endoscopic biopsies ( $>6$ ) showing invasion of the gastric mucosa by lymphoid tissue. The infiltrate consisted of small lymphoid cells mixed with medium and occasionally large cells. Small cells were lymphocytes with either a small round nucleus or an irregular nucleus giving a centrocyte like appearance. Large cells

TABLE III Histological and immunohistochemical findings

\begin{tabular}{|c|c|c|c|c|c|c|}
\hline \multirow{2}{*}{$\begin{array}{l}\text { Case } \\
\text { no }\end{array}$} & \multirow{2}{*}{$\begin{array}{l}\text { Lymphoepithelial } \\
\text { lesions }\end{array}$} & \multirow{2}{*}{$\begin{array}{l}\text { Centrocyte like } \\
\text { cells }\end{array}$} & \multirow{2}{*}{$\begin{array}{l}\text { Follicular } \\
\text { centres }\end{array}$} & \multicolumn{3}{|c|}{ Immuno-phenotype } \\
\hline & & & & Ig & $C D 5$ & $I g D$ \\
\hline 1 & + & + & - & IgM Kappa & - & - \\
\hline 2 & + & $+t$ & - & ND & ND & ND \\
\hline 3 & + & + & - & IgM Kappa & - & - \\
\hline 4 & + & + & + & ND & ND & ND \\
\hline 5 & + & + & + & IgM Kappa & - & - \\
\hline 6 & + & + & + & ND & ND & ND \\
\hline 7 & $+t$ & ++ & - & IgM Lambda & - & - \\
\hline 8 & + & + & - & IgM Lambda & - & - \\
\hline 9 & ++ & ++ & - & IgM Lambda & - & - \\
\hline 10 & + & + & ++ & IgM Kappa & - & - \\
\hline 11 & + & + & - & IgM Kappa & - & - \\
\hline 12 & + & ++ & - & IgM Kappa & - & - \\
\hline 13 & + & ++ & - & IgM Lambda & - & - \\
\hline 14 & + & + & - & IgM Lambda & ND & ND \\
\hline 15 & + & ++ & - & ND & ND & ND \\
\hline 16 & + & ++ & - & IgM Kappa & - & - \\
\hline
\end{tabular}

$\mathrm{ND}=$ Not done with a centroblastic aspect were rare. Superficial plasma cells infiltrated underlying lymphoid cells. Residual crypts were rare or absent. Characteristic lymphoepithelial lesions (lymphoid cells invading gastric glands) were found in every case. In half the specimens studied these lesions were found only after careful examination of numerous sections and staining with an anti-cytokeratin antibody. A lymphoid follicle was seen in two cases. Erosions and ulcerations were generally present.

\section{Surgical specimens}

Two surgical specimens were examined. In patient 4 , who had been operated on before being referred to our institution, neoplastic cells including centrocyte like appearance infiltrated the mucosa, submucosa, and stomach muscles, with sparse extensions into the perigastric conjunctive tissue. Characteristic lymphoepithelial lesions and rare lymphoid follicles were present. In patient 10, who had been operated on for a bleeding ulcer seven years previously, a gastric lymphoma was diagnosed on the basis of biopsy specimens. A review of the surgical specimen showed that the gastric mucosa contained very numerous lymphoid follicles with follicular centres suggestive of benign lymphoid infiltration. The follicles were surrounded by a population of small round lymphocytes, intermingled with a few small cleaved cells and centrocyte like appearance. A small number of gastric glands exhibited characteristic lympho-epithelial lesions. Proliferation was limited to the mucosa and submucosa. These features led to the retrospective diagnosis of low grade MALT lymphoma.

\section{Immunohistochemical findings}

Immunohistochemical findings are given in Table III. Lymphoepithelial lesions were shown on deparaffinised sections using anticytokeratin and antiepithelial membrane antibodies.

In the 12 cases in which cryostat sections were studied, tumour cells expressed CD 19 and CD $22 \mathrm{~B}$ cell antigens, indicating a B cell origin. Kappa light chain restriction was present in eight cases and lambda light chain restriction in four cases. Tumour cells exhibited the $\operatorname{IgM}+\mathrm{ve}$, IgD-ve, CD 5-ve phenotype. These histopathological results were consistent with the diagnosis of MALT lymphoma.

\section{STAGING}

The lymphoma was localised within the gastric wall with no evidence of regional lymph node involvement (stage I) in eight patients. Eight patients had stage IV disease, because of bone marrow involvement in two patients and/or lung involvement in seven. Lung involvement was suspected on the basis of $x$ ray abnormalities and was confirmed histologically in a surgical biopsy specimen in three cases and in a transbronchial biopsy specimen in one. No biopsy was performed in the other cases but the lung opacity on the chest $x$ ray or computed tomogram had the same macroscopic aspect as in the cases of proved 
TABLE IV Macroscopic aspect of lung involvement in seven patients

\begin{tabular}{rll}
\hline $\begin{array}{l}\text { Case } \\
\text { no }\end{array}$ & Chest radiograph and computed tomogram & $\begin{array}{l}\text { Histological } \\
\text { proof }\end{array}$ \\
\hline 9 & Round opacity of $4 \mathrm{~cm}$ in right lung & - \\
10 & Round opacity of $2 \mathrm{~cm}$ in left lung & - \\
12 & Bilateral opacities and diffuse shadowing & + \\
13 & Round opacity in right lung (1977) & + \\
& Round opacity in left lung (1983) & + \\
14 & 2 round opacities of 2 and $5 \mathrm{~cm}$ in left lung & + \\
15 & Round opacity of $5 \mathrm{~cm}$ in left lung & - \\
16 & Bilateral opacities with diffuse shadowing & + \\
\hline
\end{tabular}

lung lymphoma and responded to chemotherapy as well as the gastric lesion. The macroscopic aspect of the lung involvement is described in Table IV. Gastric endosonography, performed in patient 9 , who had thickening of gastric folds in the body and the antrum at endoscopy (Table II), showed massive infiltration of the gastric wall together with perigastric lymph node enlargement.

\section{TREATMENT AND OUTCOME}

Fourteen patients were initially treated with cyclophosphamide, one with polychemotherapy, and one with surgery and irradiation. Treatment efficacy could be evaluated in 14 of the 16 patients. Two patients (nos 3 and 5) were lost to follow up. The mean duration of follow up in the 14 remaining patients was 4.5 years (range: $1-7 \cdot 5$ years).

Four of the six evaluable stage I patients were treated with cyclophosphamide. Patient 4 who had been operated on before referral received additional radiation therapy. Another patient (no 7), who presented with a bulky tumour of the gastric body was treated with a polychemotherapy CHOP regimen (cyclophosphamide, hydroxyldaunomycin, oncovin, and prednisone) +radiation therapy. Complete remission was obtained in six patients including four treated with cyclophosphamide, with a follow up ranging from $1 \cdot 5-7$ years.

The eight patients with stage IV disease received cyclophosphamide. All these patients are alive after a follow up ranging from 1 to $7 \cdot 5$ years. Four are in a first complete remission and one in partial remission. Three relapsed at 6 years $(n=2)$ and 7 years $(n=1)$. One of these latter patients (no 13) was operated on for an obstructive small bowel relapse and in this patient, as in the two others, gastroscopy and chest computed tomography showed both lung and gastric recurrences. All three patients who relapsed responded again to cyclophosphamide. Repeated gastric biopsies did not show progression to a higher grade lymphoma in any of the patients.

Chemotherapy was well tolerated and no cases of myelodysplastic syndromes were observed despite follow up exceeding two years in seven patients treated with alkylating agents.

\section{Discussion}

All the patients we studied fulfilled the histological and immunocytological criteria established by Isaacson et al for the diagnosis of low grade B cell lymphoma of MALT. ${ }^{13}{ }^{14}$ Histo- logical examination showed small and medium sized lymphoid cells (centrocyte like cells) invading gastric glands to form characteristic lymphoepithelial lesions. In some cases, the proliferation surrounded and sometimes invaded reactive $B$ cell follicles. Immunohistochemical studies showed a B cell origin of the lymphoma, as well as the $\operatorname{Ig} M+v e, \operatorname{IgD}-v e, C D 5-v e$ phenotype.

The clinical presentation of our patients confirmed previous reports of the non-specific nature of digestive symptoms, clinical indolence, and the slow course in low grade gastric MALT lymphoma. ${ }^{12}{ }^{13}$ All the patients had complained of chronic epigastric pain for years before diagnosis and eight had a past history of recurrent gastric ulcer, gastrointestinal bleeding, or gastritis. The endoscopic aspect of the gastric lesions was clearly suggestive of malignancy in only half the patients. In the remaining cases, the endoscopist described erythematous gastritis, small nodules or thickening and erosions of gastric folds suggestive of a benign condition. This explains how the disease can be misdiagnosed over a long period and stresses the need for biopsy specimens whatever the type of gastric lesion. In patient 9, endosonography showed that there was no relationship between the endoscopic aspect and the locoregional extension of the lymphoma. Although the endoscopic changes were minimal (only mild thickening of gastric folds), endosonography disclosed massive infiltration of the gastric wall associated with an enlargement of regional lymph nodes. This observation illustrates the usefulness of endosonography in the staging of low grade gastric lymphoma. ${ }^{21}$

The chronic nature of the symptoms, the benign appearance of the gastric lesions on endoscopy, and the equivocal histological aspect of the lesions account for the fact that numerous MALT lymphomas were considered 'pseudolymphomas' ${ }^{47}$ until the monoclonal nature of the proliferation could be routinely shown by immunochemistry. In our series, two patients (nos 3 and 9) were diagnosed as having pseudolymphomas 3 and 10 years respectively before the diagnosis of MALT lymphoma. In both cases a review of previous biopsy specimens showed the presence of lympho-epithelial lesions clearly indicative of malignancy. ${ }^{1522}$ This typical lesion was also present on the surgical specimen from patient 10 who had undergone surgery for a 'bleeding ulcer' seven years before the definitive diagnosis.

Our results show that low grade gastric MALT lymphoma can be readily diagnosed on the basis of biopsy specimens. Lymphoepithelial lesions are observed on fixed tissues and immunohistochemical studies of fixed tissues can help to show these lesions with the aid of anti-cytokeratin or -epithelial membrane antibodies. Finally, immunohistochemical analysis of frozen tissue sections clearly shows the monoclonal nature and B cell phenotype of the proliferation, together with the peculiar IgM+ve, IgD-ve, CD 5-ve phenotype of the tumoural cells, indicative of the MALT origin of the proliferation.

One of the most important findings in our 
study was the high frequency of extragastric locations of MALT lymphomas, present in half the patients ( 8 of 16). Interestingly, they generally affected other mucosal sites (lung, $n=7$; parotid, $n=1$; small bowel, $n=1$ ) and usually spared the peripheral lymph nodes, spleen, and bone marrow. Involvement of other mucosal sites preceded, coincided with, or followed the manifestations of the gastric lymphoma. These findings were unexpected, as most of previously published clinicopathological studies have shown that low grade B cell gastric lymphoma is a disease process confined to the stomach for years. ${ }^{172}$ However, recent studies showed that malt lymphomas, whatever the organ involved, were susceptible to spread to or to recur in other mucosal sites. ${ }^{132425}$ Although the exact frequency of extragastric localisation remains to be determined prospectively in a larger series, our observations suggest that this possibility has to be taken into account in the choice of the staging procedure and therapeutic strategy.

In previously published studies, most authors recommended surgery, arguing that low grade gastric MALT lymphomas were localised, solitary lesions that could be excised completely 6 $^{41324}$ and that endoscopic biopsy specimens could miss small foci of high grade, B cell lymphomas. ${ }^{26}$ However, in our series half the patients had a stage IV lymphoma. Among the eight with stage I disease, five had tumoural involvement of the stomach which would have required total gastrectomy, a procedure with a high morbidity rate and one that is not justified with a well tolerated, slowly progressing disease. Moreover, in one patient (no 10), the lymphoma relapsed after partial gastrectomy. We therefore favoured conservative treatment with cyclophosphamide monochemotherapy.

All the patients with stage I disease responded to therapy, and a complete remission was obtained in those $(n=4)$ treated for at least one year. In the eight stage IV patients in whom the follow up was of specially long duration (median 6 years), a complete remission was initially obtained with cyclophosphamide in every case and patients whose disease recurred several years after the initial treatment remained sensitive to monochemotherapy. Moreover, in contrast with a recent report, ${ }^{25}$ no cases of conversion to a high grade lymphoma were observed. Although cyclophosphamide was well tolerated in our patients, the risk of developing a myelodysplastic syndrome cannot be excluded. However, this long term toxicity of alkylating agents has been shown to be related to the intensity of therapy given ${ }^{27}$ and is very unlikely to occur with the low doses needed to treat our patients. Thus, in our experience, monochemotherapy is appropriate for low grade, gastric MALT lymphomas.

In conclusion, our findings show that low grade, gastric MALT lymphoma can always be diagnosed on the basis of both fixed and fresh endoscopic biopsy specimens. Extragastric involvement seems to be frequent, usually affecting other mucosal sites and particularly the lung.
Cyclophosphamide monochemotherapy procures complete remission, with only slight morbidity, and remains effective against relapses.

1 Freeman C, Berg JW, Cutler SJ. Occurrence and prognosis of extranodal lymphomas. Cancer 1972; 29: 252-60.

2 Lewin KJ, Ranchod M, Dorfman RF. Lymphomas of the gastro-intestinal tract, a study of 117 cases presenting with gastrointestinal disease Cancer 1978; 42:693-707.

3 Grody WW, Weiss LM, Warnke RA, Magidson JG, Hu E, Lewin JK. Gastrointestinal lymphoma, immunohistochemical studies of the cell of origin. Am $\mathcal{F}$ Surg Pathol 1985; 9: 328-37.

4 Tokunaga $\mathrm{O}$, Watanabe T, Morimatsu M. Pseudolymphoma of the stomach: a clinicopathologic study of 15 cases. Cancer 1987; 59: 1320-7

5 Wolf J, Spjut H. Focal lymphoid hyperplasia of the stomach preceding gastric lymphoma: Case report and review of the literature. Cancer 1981; 48: 2518-23.

6 Scoazec JY, Brousse N, Potet F, Jeulain JF. Focal malignan lymphoma in gastric pseudolymphoma: histologic and immuno-histochemical study of a case. Cancer 1986; 57 : 1330-6.

7 Brooks J, Enterline H. Gastric pseudolymphoma: its three subtypes and relation to lymphoma. Cancer 1983; 51: s76-86.

8 Eimoto T, Futami K, Naito H, Takeshita M, Kikuchi M. Gastric pseudolymphoma with monotypic cytoplasmic immuno-globulin. Cancer 1985; 55: 788-93.

9 Burke J, Sheibani K, Nathwani B, Winberg C, Rappaport H. Monoclonal small lymphocytic proliferations of the gastrointestinal tract resembling lymphoid hyperplasia: a neoplasm of uncertain malignant potential. Hum Pathol 1987; 18: $1238-45$.

10 Spencer J, Diss T, Isaacson P. Primary B-cell gastric lymphoma: a genotypic analysis. Am $\mathcal{F}$ Pathol 1989; 135: 557-64.

11 Sigal S, Saul S, Auerbach H, Raffensperger E, Kant J, Brooks J. Gastric small lymphocytic proliferation with immunoglobulin gene rearrangement in pseudolymphoma versus globulin gene rearrangement in pseudolymph
lymphoma. Gastroenterology 1989; 97: 195-201.

12 Moore I, Wright D. Primary gastric lymphoma - a tumor of mucosa - associated lymphoid tissue. A histological and immunohistochemical study of 36 cases. Histopathology 1984; 8: 1025-39.

13 Isaacson P, Spencer J, Finn T. Primary B-cell gastric lymphoma. Hum Pathol 1986; 17: 72-82.

4 Myrhe M, Isaacson P. Primary B-cell gastric lymphoma. A reassessment of its histogenesis. F Pathol 1987; 152: 1-11.

15 Isaacson P, Wright D. Extranodal malignant lymphoma arising from Mucosa-Associated-Lymphoid-Tissue. Cancer 1987; 53: 2515-24.

16 Saraga P, Hurlemann J, Ozzello L. Lymphomas and pseudolymphomas of the alimentary tract. An immunohistochemical study with clinicopathologic correlations. Hum chemical study with clinico

17 Cogliatti SB, Schmid U, Schumacher U, Eckert F, Hansmann ML, Hedderich J, et al. Primary B-cell gastric lymphoma: A clinicopathological study of 145 patients. Gastroenterology 1991; 101: 1159-70.

18 The non-hodgkin's lymphoma pathologic classification project. National Cancer institute sponsored study of classifications of non hodgkin's lymphomas. Summary and description of a working formulation for clinical use. Cancer 1982; 49: 2112-35.

19 Cordell JL, Falini B, Erber WN. Immunoenzymatic labelling of monoclonal antibodies using immune complexes of of monoclonal antibodies using immune complexes of phatase (APAAP) complexes. F Histochem Cytochem 1984; 32: 219-29.

20 Carbone PP, Kaplan HS, Musshoff K. Report of the committee on Hodgkin's disease staging classification. Cancer Res 1971; 31: 1860-1.

21 Tio TL, den Hartog Jager FCA, Tytgat GNJ. Endoscopic ultrasonography of non Hodgkin lymphoma of the stomach. Gastroenterology 1986; 91: 401-8.

22 Isaacson P, Wright D. Malignant lymphoma of MucosaAssociated-Lymphoid-Tissue. A distinctive type of B-cell lymphoma. Cancer 1983; 52: 1410-6.

23 Isaacson PG, Spencer J. Malignant lymphoma of mucosaassociated lymphoid tissue. Histopathology $1987 ; 11: 445-62$.

4 Addis BJ, Hyjek E, Isaacson P. Primary pulmonary lymphoma: a re-appraisal of its histogenesis and its relationlymphoma: a re-appraisal of its histogenesis and its relationship to pseudolymphoma and lymphoid interstitial
pneumonia. Histopathology 1988; 13: 1-17.

pneumonia. Histopathology 1988; 13: 1-17.
$25 \mathrm{Li} \mathrm{G}$, Hansmann L, Zwingers T, Lennert K. Primary lymphomas of the lung: morphological, immunohistolymphomas of the lung: morphological, immunohisto-
chemical and clinical features. Histopathology 1990; 16: 519-31.

26 Chan JK, Isaacson P. Relationship between high-grade lymphoma and low-grade B-cell Mucosa-Associated Lymphoid Tissue Lymphoma (MALToma) of the stomach. Am F Pathol 1990; 136: 1153-64

27 Koeffler HP. Myelodysplastic syndromes. Semin Hematol 1986; 23: 284-99. 